\title{
ARTICLES
}

DOI: $10.17803 / 2313-5395 \cdot 2021.2 .16 .247-269$

\section{International Legal Regulation in the Field of Environmental Protection: History, Currents Situation, Prospects for the Future}

\author{
Olga I. Ilinskaya \\ Kutafin Moscow State Law University (MSAL), Moscow, Russia
}

\begin{abstract}
The international agreements and treaties in the field of environmental protection, concluded in the 19th - first half of the 20th century, resulted most commonly from the compromises of necessity; they merely intended to deal with urgent matters on a limited scale in the spheres where specific problems emerged or at least were a focus of attention (e.g. some species under the threat of extinction, pollution of a specific area of the marine environment). These cases were reasons for adoption of conventions, aimed at protecting endangered species or preventing marine pollution. Such a fragmented approach to the issues of environmental protection shaped a set of conventions, impressive by its amount, but extremely diverse in its content.

The understanding of the ecosystems' integrity resulted in the development of the principles, enshrined in the 1972 Stockholm Declaration and in the 1992 Rio Declaration, was to a significant degree driven by the spectacular advances in science and technology. As a result, the transition has been under way from the "spontaneous" formation of the international environmental standards to their consolidation around the special principles of international environmental law.

Also a notable feature of many international environmental agreements - their "framework" character - is further analyzed. The adoption of the framework agreements gives rise to the complex sets of the convention documents, consisting of several different, but in a certain way interrelated agreements.

Treating a question of the effectiveness of such a legal instrument as a framework agreement, the author concludes that the origins of the lack
\end{abstract}


of effectiveness of the environmental agreements lie in the foundations of the existing economic system.

Keywords: international agreement (treaty), environmental protection, effectiveness of international agreements, international environmental law, international framework agreement

Cite as: Ilinskaya, O.I., (2021). International Legal Regulation in the Field of Environmental Protection: History, Currents Situation, Prospects for the Future. Kutafin Law Review, 8(2), pp. 247-269, doi: 10.17803/2313-5395.2021.2.16.247-269 (In Eng.).

\section{Contents}

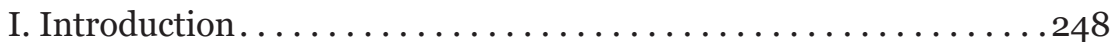

II. The Early International Treaties in the Field| of Environmental Protection ......................249

III. Shaping a System of Principles in International

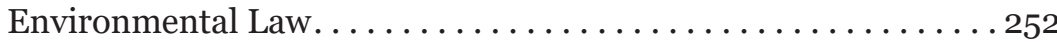

IV. The Role of Non-Governmental Actors . . . . . . . . . . . 256

V. The Framework Agreements in the Field of Environmental Protection .......................258

VI. The Improvement of the Effectiveness of the Rules of the International Environmental Law: Utopia or Reality? . . . . . . . 266

VII. Conclusion . . . . . . . . . . . . . . . . . . . . . . . . . 262

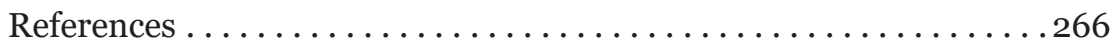

\section{Introduction}

The development of the international legal norms in the field of environmental protection (the term "environmental protection", it should be noted, semantically speaking, refers both to environmental defense and environmental preservation: "Guard... control... protect... preserve... conserve... save" (Dal, 1979, p. 774) relies on the same legal forms as the other areas of intergovernmental cooperation international agreement, customary international law, and, in some cases, resolutions by international institutions.

The isolated efforts to protect the environment by means of international law date back to the 15th century. Indeed, the first 
ever-known international arbitration, that addressed the issue of environment protection and management, took place as early as in the beginning of the 15th century, with reference to resolution of various border disputes (Abashidze, 2012, p. 252). At that time such issues of environmental protection as transboundary water disputes and the relevant coordinated sustainable management of marine and river resources were addressed while arbitrating international disputes (Abashidze, 2012, pp. 252-253).

\section{The Early International Treaties in the Field of Environmental Protection}

It was not until the 19th century that the early international legal rules, aimed at sustainable use of the bioresources, first appeared. According to M.N. Kopylov (2007, p. 54), a prominent specialist in the field of international environmental law, "it is the bilateral Convention on ostreaculture and fisheries off the coast of Great Britain and France, signed on the 2nd of August, 1839, that can be treated as the first international agreement regarding the arrangement of the international environmental relations."

Since the second half of the 19th century - early 20th century the international agreements, aimed to preserve some species which were in danger of passing away due to the unsustainable utilization (virtually, extirpation), or forced to leave their man-modified habitats, have been concluded more often. Just to name a few, these are the Treaty concerning the Regulation of Salmon Fishery in the Rhine River Basin (1885), the Agreement between the United Kingdom and Russia for the Preservation of the Sea-lions in the North Atlantic Ocean (1893), the Agreement between Russia, the United States and Japan for the Preservation of the Fur-seals (1897), the Paris Convention for the Protection of Birds useful to Agriculture (1902). However, the protection of these species of fauna served as a matter of fact just as an instrument; the objective of all the agreements of this kind stemmed from the reasoning of a different - economical - order, namely from the intention to encourage some business activities (agriculture, fishery, hunting). For instance, the above-mentioned 1897 tripartite 
agreement stipulates in article I, that "the High Contracting Parties agree to prohibit their respective subjects and citizens from killing the fur seal and sea otter... for the period of one year (emphasis added. O.I.) from the date of this Convention..." It is obvious that the defined duration of prohibition was dictated by the need to maintain and restore populations of these species at levels which can produce the maximum sustainable yield. The aforesaid objective has been made explicit in the very title of the last-mentioned document.

The agreements, concluded in more recent times, which extended the protection to include particular environments, were thereby facilitative of the protection of the local flora and fauna. This is true with the issue of protection of both the land territories (e.g. the Convention on Nature Protection and Wild Life in the Western Hemisphere, 1940) and the water resources (e.g. the Treaty Between the United States and Great Britain Relating to Boundary Waters, 1909). The same holds true for the maritime spaces (e.g. the International Convention for the Prevention of Pollution of the Sea by Oil, 1954). The treaty sources in question, by protecting the territories, thereby ensured the protection of flora and fauna and provided, in our opinion, a breakthrough for the cause of the international legal environmental protection, as they revealed a greater, more ecology-minded perspective. In other words, the significance of the environmental conditions for the preservation of flora and fauna has finally been appreciated.

Nonetheless, norms of international environmental law, developed in haste, often in the aftermath of natural disasters or due to the anthropic activity, looked initially somewhat patchy. As a result of a forced compromise, rather than a yearned-for trade-off, these norms were intended to deal with the most urgent matters on a limited scale in the areas, where specific problems emerged or at least were a focus of attention (some species under the threat of extinction, unwarranted pollution of the specific marine environment). These cases were reasons for the adoption of conventions, aimed at protecting endangered species or preventing marine pollution. For instance, the shipwreck of the Liberian oil tanker "SS Torrey Canyon", that sank after running aground off the western coast of Cornwall, England, in 1967, initiated the worldwide presentation of a problem of an incident pollution control. This 
issue is so nuanced, since in view of the urgency of the decisions to be taken, the closest coastal States, or the most threatened States, should be empowered to intervene, even if it is done to the detriment of the traditional prerogatives of the flag State, in the event that the latter fails to take the necessary measures. A major step forward was made in the wake of the adoption of the International Convention Relating to Intervention on the High Seas in Cases of Oil Pollution Casualties, 1969. This Convention affirms the right of a coastal State to take any enforcement measures in respect to any vessel on the high seas provided that the given conditions are met. The article I of this international legal act stipulates, "1. Parties to the present Convention may take such measures on the high seas as may be necessary to prevent, mitigate or eliminate grave and imminent danger to their coastline or related interests from pollution or threat of pollution of the sea by oil; following upon a maritime casualty or acts related to such a casualty, which may reasonably be expected to result in major harmful consequences." With regard to the above mentioned, article III (d) states that "in cases of extreme urgency requiring measures to be taken immediately, the coastal State may take measures rendered necessary by the urgency of the situation, without prior notification or consultation or without continuing consultations already begun (these notifications and consultations are mentioned in other paragraphs of the same article. O.I.)."

This kind of a "fragmented" and "mechanical" environmental policy throughout the 19th century resulted in a set of conventions, impressive by its amount, but diverse in its content. It is also specific that the convention sources are for the most part regional (subregional), what can be explained, according to O.S. Kolbasov (1982, p. 216), by several interrelated reasons. First, the variety of ecosystems, inherent in the natural regions of Earth, results in the environmental problems, which differ in terms of their substance and significance. Second, different levels of economic development in different regions have an impact on the societies' environmental dimension as well as disparities in social conditions. And these agreements facilitate a solution to the great majority of the specific international environmental problems, and the regional arrangements' system itself "complements, pushes and 
bolsters" the universal agreements. Certainly, it is difficult to disagree with this statement. Still, we must not overlook the fact that the ad hoc regulations, as described above, where a particular treaty source appears in reaction to the emerged environmental concern, may raise grave questions. As N.A. Sokolova emphasized (2014a, p. 12), "there are many agreements, dealing with the specific problems without regard to the rules and standards set by other agreements, resulting in the issues of their interaction and correlation in the way of the content and organization alike. This situation is bound to loosen the global system of environmental protection."

Giving his assessment to the process of formation of the branch of international law in question, as M.N. Kopylov pointed out correctly (2007, p. 240), that the history of international environmental law represented a series of less-than-prompt (at times ill-fated) responses to the sharply deteriorating situations of environmental crisis.

\section{Shaping a System of Principles in International Environmental Law}

The rapid progress of science and technology catalyzed the realization of the ecosystems' integrity, the fact evidenced in the elaboration of the entire system of principles, enshrined in the Declaration of the United Nations Conference on the Human Environment (the 1972 Stockholm Declaration) and in the Rio Declaration on Environment and Development (the 1992 Rio Declaration). It paved the way, as A.S. Timoshenko puts it (1992, p. 287), for the transition "from the spontaneous formation of the international environmental standards to their consolidation around the special principles of international environmental law and foundation of the sectoral research institutes." However, most of the principles, listed in the acts mentioned above, cannot be classified as regulatory ones (Kiss, 1997, pp. 34-35). In the capacity of optimization requirements they set out the objective of the optimum implementation of a specific "ideal task" (Vitzthum, 2011, p. 586). Still we cannot subscribe to the opinion, advanced by W.G. Vitzthum (2011, p. 583), who states that "the Rio Declaration on Environment and Development consists of 27 non-legally binding 
(emphasis added. - O.I.) principles...” A similar estimation of the principles, enshrined in the 1972 Stockholm Declaration, the 1992 Rio Declaration, the World Charter for Nature, adopted in 1982, is given by Yu. S. Shemshuchenko (2009, p. 82), who argues that "the environmental principles, enshrined in them (afore-mentioned international acts), represent as a matter of fact the general guidelines for the respective countries." It is obvious that by no means all of the principles, listed in the Rio Declaration, can be referred to as "non-legally binding" ones. For instance, the principle of international law, whereby no damage can be caused to the environment of other States or areas beyond national jurisdiction, was cited as early as in 1938, in the arbitration award in the Trail Smelter dispute (a US-Canada dispute, caused by the fact that the harmful air emissions, produced by the smelter, processing lead and zinc in the Canadian town of Trail, damaged the environment across the US-Canada border in the State of Washington). The arbitral tribunal found that "under the principles of international law, as well as the law of the United States, no State has the right to use or permit the use of the territory in a manner as to cause injury by fumes in or to the territory of another or the properties or persons therein, where the case is of serious consequence and the injury is established by clear and convincing evidence." ${ }^{1}$ The international legal norm, prohibiting the State to alter the natural conditions on its territory in a manner as to cause injury by this alteration to other State, was cited in the arbitration award on the Lake Lanoux dispute (France v. Spain), rendered in $1957 . .^{2}$ The reasons for this arbitration were the French plans to construct a reservoir for the purpose of producing electricity at Lake Lanoux. Spain opposed the plan out of concern that the water diversion, envisaged by the French scheme, may have an adverse affect on the runoff volume of the river Carol that has its rise in this lake and flows across Spain. Reacting to Spain's objections France agreed to modify the original scheme, so that Spain could obtain comparable or even larger volume of water through its diversion from the river Ariège. This project was rejected by Spain as well, which led to the

${ }^{1}$ Trail Smelter Arbitration (United States v. Canada), (1957). United Nations Reports of International Arbitral Awards, 3, p. 1965.

${ }^{2}$ Lake Lanoux Case, (1957). International Law Reporter, 24. 
arbitration after all. The Tribunal took the French side and pointed out that the Spanish complaints would have been justified only if the pollution of water or changes in its chemical composition, temperature or other properties were evident.

According to A.S. Timoshenko (1992, p. 294), the quoted decisions not only highlighted the applicability of the general law principle sic utere tuo ut alienum non laedas ("use your property in such a way that you do not damage others") to the interstate environmental relations, they also facilitated the formation of the special principle of international environmental law, prohibiting one State to change the natural conditions on its territory in a manner as to have a disadvantageous effect upon the environment of other States. The inadmissibility of the State's use of its territory to the detriment of the rights of the other States is articulated as well in the judgment of the UN International Court of Justice (ICJ), issued in 1949 in the Corfu Channel case (United Kingdom of Great Britain and Northern Ireland against People's Republic of Albania). The Court reiterated in particular the principle that "every State is obliged not to knowingly allow its territory to be used to commit acts against the rights of any other State." 3 The scholarly literature typifies this Court's finding as an acknowledgement of the existence of the generally recognized rule of international law (Sokolova, 2003, p. 101).

It should also be noted that many States have repeatedly expressed their conviction in the indispensability of the above-noted principle, incorporating it, often verbatim, in the international agreements. For instance, the article 3 of the Convention on Biological Diversity of 1992 contains the provision, whereby "States have... the responsibility to ensure that activities within their jurisdiction or control do not cause damage to the environment of other States or of areas beyond the limits of national jurisdiction."

The "polluter pays" principle, mentioned in the 1992 Rio Declaration, cannot be regarded as "non-legally binding" either. Its sources can be traced to the Recommendation of the Council of the Organization of Economic Cooperation and Development (OECD) on the "Guiding Principles Concerning International Economic Aspects

3 Corfu Channel Case, (1949). International Court of Justice. Reports, p. 22. 
of Environmental Policies" dated 26 May 1972. It should be noted that the OECD linked it to the idea of the following preventive measures: imposing the costs of pollution control and abatement measures on the polluter and limiting (or even prohibiting) the allocation of subsidies for these purposes which might distort competition. This provision is based on the idea that the economic incentives lack, if the third-party entities bear the costs, and the "polluter" is spared from taking these expenses into account (Vitzthum, 2011, p. 590).

For its part, the Council of the European Economic Community (EEC) adopted around the same time its first recommendations on the issue in question (November 7th, 1974 and March 3rd, 1975), the guidelines that were aligned with the OECD ideology and established direct connection between the competitive equality and the "polluter pays" principle. The single European Act, signed in 1986, and then the Maastricht Treaty, concluded in 1992, turned the mentioned principle into one of the cornerstones of the European environmental policy. Currently, the mentioned provision is enshrined in the Article 191, Paragraph 2 of the Treaty on the Functioning of the European Union: "Union policy on the environment shall aim at a high level of protection taking into account the diversity of situations in the various regions of the Union. It shall be based on the precautionary principle and on the principles that preventive action should be taken, that environmental damage should as a priority be rectified at source and that the polluter should pay."4

Besides, the "polluter pays" principle can be found in many regional and universal agreements, where it is either just mentioned (for instance, the article 3 of the Convention on the Protection of the Marine Environment of the Baltic Sea Area, 1992 (Helsinki Convention)) or defined more specifically (for instance, article $3 \mathrm{~b}$ of the Convention

4 The Treaty originated as the Treaty of Rome (fully the Treaty establishing the European Economic Community), which brought about the creation of the European Economic Community (EEC), the best-known of the European Communities (EC). Its name has been amended twice since 1957. The Maastricht Treaty of 1992 removed the word "economic" from the Treaty of Rome's official title and, in 2009, the Treaty of Lisbon renamed it the "Treaty on the Functioning of the European Union". The paragraph is quoted after this latest version of the Treaty. 
for Protection of the Mediterranean Sea against Pollution, adopted in 1976).

Even if it is too early to allege as a fact it has (i.e. the "polluter pays" principle. - O.I.) the universal character of an international custom," and many of its aspects are still controversial (Vitzthum, 2011, p. 590), it cannot be denied that the practices of the convention consolidation of the present principle definitely suggest the States' conviction in its indispensability.

Therefore, one can talk about varying degrees of the "normative maturity" of the principles, enshrined in the Rio Declaration: some of them are in fact forward-looking and can be rightfully qualified as the "principles-targets" (for instance, the Principle 8, whereby "...States should reduce and eliminate unsustainable patterns of production and consumption and promote appropriate demographic policies," Principle 21 proclaiming the necessity "to mobilize the creativity, ideals and courage of the youth of the world," etc.), whereas other principles (including those mentioned above) are applicable international legal norms.

\section{The role of Non-Governmental Actors}

When analyzing the contractual practice of the states in the field of the environmental protection, it is possible to confirm that the subjects of legal relations themselves have a significant impact on it. It is obvious that the complexity of the influence over the pollution and its sources, the costs of the required actions, their economic significance, technical nature of the emerging challenges and their global dimension have an impact both on the ways to develop the treaties and on their contents.

One of the most noteworthy characteristics of international environmental law is connected with the role of the non-governmental structures in its development and realization. On the one hand, the economic entities are the principal polluters and holders of environmental protection technologies. In this respect, they are, directly or indirectly, principal addressees of the norms of international environmental law, whose technique should adapt to the situation, and this adaptation 
appears to be most needed and most complicated in the questions of liability for environmental damage.

On the other hand, the environmentalists unite their efforts in powerful non-governmental organizations (including the most militant or, in any event, the best-known of them, like Greenpeace, Friends of the Earth International, World Wide Fund for Nature, Équipe Cousteau, formerly known as Fondation Cousteau). They do double service as nongovernmental organizations for promoting sustainable development of the emergent nations and as pressure groups, aspiring to advocate environmental values and to facilitate their transformation into legal norms. As for their activities in the field of developing international standards, the most common of them would be the experience of the active presence at the international conferences dedicated to the adoption of the legal instruments, dealing with the protection of the environment. Indeed, the non-governmental organizations played an instrumental role in the United Nations Conference on the Human Environment, that was held in Stokholm in 1972, where the concept of sustainable development was first discussed, in the United Nations Conference on Environment and Development, held in Rio de Janeiro in 1992, and in all the subsequent diplomatic conferences they engaged in on an official basis. Although they do not sign the adopted acts, they are offered an opportunity to address the conferences and to circulate their documents. A.S. Timoshenko (1986, p. 39) singles out such an example. The International Union for Conservation of Nature and Natural Resources, using its consultative status at the United Nations, is in a position to express itself officially on the draft documents planned to be discussed at broad, representative international forums, in intergovernmental bodies (for instance, the third United Nations Conference on the Law of the Sea (UNCLOS III), the International Whaling Commission).

The observers for 400 non-governmental organizations participated in the Stokholm Conference on the Human Environment in 1972, and 1400 non-governmental organizations were accredited to the Conference in Rio de Janeiro (Lukashuk, 2005, p. 182). It is interesting to note that non-governmental organizations that participated in the Rio Conference, gained an observer status at the UN Commission on 
Sustainable Development whose functions are "to enhance the dialogue... with non-governmental organizations" and "to receive relevant input... in the context of the overall implementation of Agenda 21." ${ }_{5}$

If a conference results in the adoption of an international agreement, then the representatives of the non-governmental organizations can participate in the activities of the agencies that control its implementation, when the agreement provides such an opportunity. For instance, the Article 12 paragraph 2 of the 1995 Agreement for the Implementation of the Provisions of the United Nations Convention on the Law of the Sea of 10 December 1982 relating to the Conservation and Management of Straddling Fish Stocks and Highly Migratory Fish Stocks, contains a provision according to which "representatives from non-governmental organizations concerned with straddling fish stocks and highly migratory fish stocks shall be afforded the opportunity to take part in meetings of subregional and regional fisheries management organizations and arrangements as observers or otherwise, as appropriate, in accordance with the procedures of the organization or arrangement concerned."

\section{The Framework Agreements in the Field of Environmental Protection}

As for another peculiar feature of the agreements in the field of environmental protection - their contents - this feature consists, above all, in the existence of a large number of the so called "framework agreements," representing the compacts, stating the principles, which should serve as a basis for the cooperation of the States parties in a particular sphere, and giving them an opportunity to specify in separate agreements the order and details of the cooperation with creation, if necessary, of one or several relevant agencies for this purpose. Therefore, the framework agreement represents the initial stage for the subsequent conventional or institutional activities. This kind

5 UN Doc. A/Res/47/191. 29 January 1993. Available at: http://www.un.org/ documents/ga/res/47/ares47-191.htm [Accessed 20 Apr 2018].

The functions of the Commission are described in the paras 3 (f) and 3 (g) of this Resolution: To receive and analyze relevant input from competent non-governmental organizations... in the context of the overall implementation of Agenda 21; To enhance the dialogue... with non-governmental organizations... 
of activities can be expressed, in part, in the conclusion of subsequent specifying agreements or in the adoption of the protocols specifying the contents of the principles set forth in the original agreement. To sum up, the framework agreement is a rather lengthy negotiation process that obliges States to participate bona fide in the subsequent stages of negotiations, than a source of the specific obligations to be assumed by the States parties. Besides, in some cases the reference to the framework nature of such agreements is made in their titles. The United Nations Framework Convention on Climate Change adopted in 1992 can serve as an example. Its article 17 stipulates the adoption of the protocols, opened only for the parties to the Convention. According to this article, "1. The Conference of the Parties may, at any ordinary session, adopt protocols to the Convention... 4. Only Parties to the Convention may be Parties to a protocol." The 1997 Kyoto Protocol that elaborated the commitments taken in 1992, was signed on the basis of this article. A lot of other environmental agreements fall into this category of agreements. For instance, the Vienna Convention for the Protection of the Ozone Layer, signed in 1985 also had a provision regarding the adoption of protocols. According to the article 2, para 2 (c) of this Convention, the Parties "co-operate in the formulation of agreed measures, procedures and standards for the implementation of this Convention, with a view to the adoption of protocols and annexes." One of such protocols was signed in Montreal in 1987 (the Montreal Protocol on Substances that Deplete the Ozone Layer) and then was modified on several occasions. The Vienna Convention and its Protocol contain the annexes, their integral part. Similarly, the Bonn Convention on the Conservation of Migratory Species of Wild Animals of 1979 lists the species to be the subjects of separate agreements and provides the approximate frameworks for such agreements (articles IV, V). The article IV, entitled "Migratory Species to be the Subject of Agreements" inter alia stipulates, "Parties that are Range States of migratory species listed in Appendix II shall endeavor to conclude Agreements where these should benefit the species and should give priority to those species in an unfavorable conservation status." The article V that deals with the guidelines for such agreements, underlines that the object of each of them is to restore the migratory 
species concerned to a favorable conservation status or to maintain it in such a status. ${ }^{6}$

In the same spirit, the preamble of the Convention on the Law of the Non-navigational Uses of International Watercourses of 1997, asserting this international act as a "framework convention," capable of ensuring the utilization, development, conservation, management and protection of international watercourses and the promotion of the optimal and sustainable utilization thereof for present and future generations, makes provision for the States parties to enter into "watercourse agreements," which apply and adjust the provisions of the Convention: "Watercourse States may enter into one or more agreements... which apply and adjust the provisions of the present Convention to the characteristics and uses of a particular international watercourse or part thereof" (para 3, art. 3).

Therefore, the adoption of the framework agreements results in the formation of the complex sets of the convention documents, consisting of the several different, but specifically interrelated international agreements.

Estimating the practices of the conclusion of the framework agreements, M.N. Kopylov (2007, p. 153-154) noted that "through the use of its comparatively broad statements and conditions the 'framework' agreements provide the base necessary for the interaction and cooperation of the greatest possible number of States, which have different political and economical systems. And as a first step of the co-operation of efforts they let engage instantly in the research and monitoring of extreme importance, as these are the accurate scientific data on various ecological issues and their consequences that provide the possibility to move to the level of assumption of more detailed obligations by the States." According to the Ukrainian scholar M.A. Medvedeva (2012, p. 81), the practices of the framework agreements have the following advantages: first, they facilitate reaching an interstate consensus on the complicated and controversial issues through fixing most general venues of cooperation in the agreements of this kind and addressing any ecological issues immediately; second, depending upon the level of development of science and technologies in a specific field of human activity they provide the possibility to make modifications in

${ }^{6}$ United Nations Treaty Series, (1991). Vol. 1651. I-28395, pp. 421-442. 
the specifying protocols or their appendixes, without prejudice to the provisions of the framework agreement itself, thus providing for the relative flexibility of the legal regulation.

However, the "framework approach" has an inherent flaw, namely, according to M.A. Medvedeva (2010, pp. 219-247), the practice of expressing the State's consent to commit oneself to the framework convention with no serious legal obligations and at the same time its refusal to give consent to participate in the protocols containing such obligations, cancels out the result achieved at the international level. The case in view is the non-ratification by the US of the 1997 Kyoto Protocol to the UN Framework Convention on Climate Change signed in 1998.

As for the legal qualification of the norms enshrined in the framework agreements, they should be placed, beyond any doubt, into a category of the "programmed" ones. According to I.I. Lukashuk (1997, p. 198), these are, most notably, the norms, requiring the development or considerable specification. In addition, paying attention to some approaches in the academic literature, treating the program norms of international agreements as "flawed" (such is the attitude adopted, for instance, by the Italian jurist G. Arangio-Ruiz (1988, p. 82)), the scholar insisted for a very good reason that "the program nature of the norm does not deprive it of its binding force," and the non-observance of such a norm by one of the parties can be treated by another one as the rejection of the objectives of the treaty, the violation of its spirit (Lukashuk, 1997, pp. 198, 201). If there is a rejection of the program provisions of an agreement that require the conclusion of other agreements (as in above-mentioned examples), this situation should be treated as a breach of the agreement.

So, depending on the content of the program provisions of the international agreements (in some cases these may be the vague program-oriented and goal-oriented settings, while in others - program provisions are of a more specific nature), their violation can be treated either as "the rejection of the objectives of a treaty, the violation of its spirit" or as "a breach of an agreement."

While characterizing the framework environmental protection agreements, one should agree with M.N. Kopylov (2007, p. 152) that 
they are capable of facilitating a real solution to the ecological problems, as they call upon the parties to take concrete steps, aimed at restoring and maintaining the certain natural resources. The conviction in efficiency of such a legal instrument as the framework agreement was clearly expressed by the States in the preamble of the Convention on the Law of the Non-navigational Uses of International Watercourses of 1997 that says that "a framework convention will ensure the utilization, development, conservation, management and protection of international watercourses and the promotion of the optimal and sustainable utilization thereof for present and future generations."

\section{The Improvement of the Effectiveness of the Rules of the International Environmental Law: Utopia or Reality?}

All of the above should not, however, produce an impression that the sheer fact of concluding framework agreement succeeded by the adoption of a protocol (appendix, supplement etc.), specifying obligations of the parties, is a kind of a guarantee of achieving the intended effect. It should be noted that for the efficient implementation of international legal norms the favorable ratio between the goal of a norm and the means of achieving it is of great practical importance. It is worth specifying that not every international agreement articulates the goals of its conclusion in its text, but the intended result can always be deduced from the very content of the enshrined norms.

L.Kh. Mingazov (1999, p. 33) in his fundamental scientific research, devoted to the effectiveness of international law writes, "the effectiveness of the international legal norms would be high enough only in case, if the means to an end: 1) possess a real ability to materialize the goal in the objective reality; 2) ensure their most rapid, rational, full realization; 3) are compatible with the generally recognized principles of contemporary international law. In the absence of these conditions, international legal norm will surely be in effect, but this effect will not be the greatest possible one."

Speaking of the balance between the legal norms goals and the means to achieve them, the scholar notes for a very good reason that "these means include material costs as well. If the choice of means is right, 
that is the methods of solution proposed in an international agreement do not involve considerable material costs..., then it is a key factor for the efficient implementation of the provisions of this agreement" (Mingazov, 1999, p. 46). Hence, the disregard of the economical factors, inappropriate (insufficient) estimation of the existing economic potential of the State, assuming international legal obligations, results in the fact that even an international treaty, which is perfect from the perspective of legal engineering, remains a "dead letter." L.Kh. Mingazov (1999, p. 46) points to the example of the Vienna Convention for the Protection of the Ozone Layer and the Montreal Protocol on Substances that Deplete the Ozone Layer signed by the Soviet Union on March, 22, 1985 and November, 10, 1988 respectively, without sufficient expertise, without regard to the real economic potential of the country at the time making conditions for the State's failure to take action with respect to the obligations under these agreements within the span of almost 10 years.

Therefore, as early as at the stage of the preparation of the international agreements, involving considerable material (financial) costs on the part of the State, it is necessary to forecast the reasonably practicable extent of their feasibility, given the fact that the partner nations can sometimes be on the disparate levels of economic development. As it is known from the legal theory, "one cannot place delusive hopes in the law as a practical matter - it is not omnipotent. It would be naïve to demand from it more than it could admittedly give..." (Matuzov and Malko, 2001, p. 266). As N.A. Sokolova (2014b, p. 391) correctly points out, "the success of ensuring environmental security depends on the effectiveness of the implementation of the norms of international law, this being connected not only with the application of law in a broad sense, but also with the international law-making process."

And yet, it seems, it is not only and not so much about the real economic potential of the States. Equally important is their political will concerning the assumption and - above all - fulfillment in good faith of the assumed international obligations. In the absence of this condition no international agreement, no matter how explicit it is, no matter which means of securing the obligations it stipulates (for details of the control in the field in question see: Valeev, 2001; Ilyinskaya, 2010), cannot be regarded as an effective remedy of the 
legal regulation. According to L.Kh. Mingazov (1999, p. 78), "The limits (options) of the international legal influence are determined by the real conditions of the current system of international relations." That is why in the context of the motivation of industrialized States for the solution of environmental problems at the expense of developing countries it is challenging to discuss the effectiveness of agreements in the field concerned. The scientific estimation of the prospects of the reduction of the greenhouse gas emissions within existing international legal framework is quite revealing in that respect. Indeed, according to V.V. Golitsyn (2011, p. 31), these prospects "appear utopian," and "the mechanisms of the Convention (referring to the UN Framework Convention on Climate Change. - O.I.) and of the Kyoto Protocol to it do not work." This conclusion is based, in particular, on the fact that "the European countries, which have technically reduced greenhouse gas emissions, in practice exported them to the developing countries by way of outsourcing" (Golitsyn, 2011). In view of this, the scholar believes on reasonable grounds that "in the absence of the worldwide system of the greenhouse-gas emission reductions, obligatory for all countries, meeting targets of the Framework Convention would be extremely difficult, if not impossible" (Golitsyn, 2011, p. 32). As we can see, this difficulty (or even impossibility) is due not to lack of the required economical possibilities of the State. The reluctance of industrialized States to reduce the excessively high levels of production and consumption, their practices of addressing environmental issues at the expense of developing countries were described quite bluntly by M.N. Kopylov (2000, p. 8): "The pragmatic industrialists... in seeking to produce the quickest returns from the respective capital investments and to generate the dividend as soon as possible, as a rule... think of anything but the compliance with the strict 'western' standards and technologies on the territory of the developing countries to the same degree as on the territory of the developed States. In this case they tap into a new market (by way of the export of the faulty technologies, going beyond the scope of the above-mentioned technologies and standards) for an entirely different reason." In the light of such realities the words of the French scientist Ph. Saint-Marc (1977, p. 54), written in the 1970s, are even more relevant today, "It would be a strange self-deception to think that it is possible to preserve nature leaving intact the very economic system that 
destroys it." This statement is quite clear. And here one can conclude that the talk of scope for doing more to improve the effectiveness of international legal rules in the field of the environmental protection by way of their codification in the specific international agreements, though well-argued and, besides, widespread in the scientific community, deals actually only with the technical legal matters. A.S. Timoshenko (1986, p. 33), for instance, wrote that "the codification of the environmental protection legislation in the special international treaties would raise its effectiveness thanks to the better mutual coordination of the norms, the feasibility of the combined effect... The codification of the rules of the environmental protection, both customary and agreementbased, in the universal convention of a comprehensive nature would be of fundamental importance for the development of environmental law as a branch of international law." The importance of the codification in this field is noted by P. Malanczuk (1997, p. 245), who points to the fact that it is impossible to talk about the consistency of the current international environmental law. Yu.S. Shemshuchenko (2009, p. 82) also emphasizes the need for codification. It appears to him that the founding act of the codification of the international environmental law, the top of its pyramid should be the Environmental Constitution of the Earth (optionally - The Environmental Codex of the Earth). And in the early 1990 s it was Ukraine that came forward with an initiative of adopting the World Environmental Constitution (Repetski et al., 2012, p. 387). In this context one important thing is overlooked: the mainstay of raising the effectiveness of the norms of international environmental law (as well as all other international legal norms) is the political will of the States, and in its turn it is bound to be determined by the existing economical system. The States, in course of shaping and implementing their economic policies, should take into account the real capabilities of the nature to meet the needs of society and development. As M.M. Brinchuk (2010, p. 11) notes, this requirement for the economically developed States is becoming an imperative. In the meantime, he calls attention to the need of adjusting the very concept of the needs of States. The scholar is convinced that "in the context of the scarcity of natural resources, objective inability of the nature to reproduce them in at a scale appropriate for the 'needs' of the world market economy, what really needs adjustment and improvement is this 
economy itself, is its modus operandi. This improvement should take place reflecting the development of the concept of public needs, to be met by the market; the combination of the principles of the freedom of the market and that of planning and managing natural resources. The 'hybrid' approach, combining the elements of the socialist and capitalist economies, should be applied. Acting in such a way, the global economy may build only on the limit on usage of such a volume of natural resources that the nature can reproduce during the relevant period" (Brinchuk, 2010, p. 12). of course, addressing such issues can and should be based only on international law.

Unfortunately, however, we are obliged to admit that all the calls for the improvement of the economical system remain unheard. Speaking of the development of the existing economical system in its worst, destructive, manifestations, M.M. Brinchuk (2010) aptly describes it as a system that "submits all and everything, especially the nature as its principal resource, to its selfish interests." In our view, one cannot but agree with this statement. Indeed, without the improvement of the existing economical system the efficiencies of the norms of international environmental law are unlikely to be achieved. of course, the conclusions of this kind may seem too abstract, since they do not contain the precise answer to the key question here - who and how might be able to (if it is possible at all) initiate this process on a global scale?

\section{Conclusion}

Once the Minister of Ecology and Natural Resources of the Russian Federation V.I. Danilov-Danilyan (1992, p. 69), interviewed by "The Moscow Journal of International Law," proclaimed, "Everything what is intolerable in terms of ecology, is ineffective in terms of economics." This assessment seems to be quite fair. Simultaneously, the question arises: do the States always comply with the decisions taken in the exercise of their powers, with their unconditional duty of the environmental protection? The answer to this question, as shown above, is negative. The fact of China's non-participation in the Convention on Long-Range Transboundary Air Pollution of 1979 could be an indication that not all industrialized nations are prepared to assume the international obligations in the field of the environmental protection, involving 
certain (sometimes very significant) restrictions of the economic benefits of these countries (which means additional investment in the modernization of production facilities). Meanwhile, in the world list of countries producing most carbon dioxide emissions China ranks second after the United States. ${ }^{7}$ It is worth mentioning here that in 2017 then-United States President Donald Trump announced that the U.S. would cease all participation in the 2015 Paris Agreement on climate change mitigation. ${ }^{8}$ According to Trump, this agreement disadvantages the United States to the exclusive benefit of other countries, and, if implemented, it would cost the USA 2.7 million jobs by 2025. The US implementation of this accord would be, in Trump's opinion, "the draconian financial and economic burden" for the country. However, by now the US foreign policy regarding the participation of the State in the Agreement mentioned above has drastically changed. The newly elected US President, an ecologically conscious Joe Biden, signed an executive order to rejoin the Paris Agreement as early as on January 20, 2021, his first day in office. "We have lots of possibilities. We can overcome the climate change danger. I do believe in it," he said. ${ }^{9}$ Surely, this move should only be commended.

So ultimately, we have to conclude that the root causes of the problem of the lack of effectiveness of international environmental agreements lay, as we see it, in the foundations of the existing economic system.

\section{References}

1. Abashidze, A.Kh., (2012). The pacific settlement of international disputes: modern problems: A monograph, 2nd ed. Moscow: Peoples Friendship University of Russia. (In Russ.)

7 Available at: http://tass.ru/mezhdunarodnaya-panorama/4300291 [Accessed 20 Sept 2018].

${ }^{8}$ White House Press Release, President Donald Trump, Statement on the Paris Climate Accord (June 1, 2017). Available at: https://www.whitehouse.gov/thepress-office/2017/06/01/statement-president-trump-paris-climate-accord [Accessed 20 Sept 2018].

9 The United States rejoin the Paris Agreement on climate (January 21, 2021). Available at: http://tass.ru/mezhdunarodnaya-panorama/10510151 [Accessed 25 May 2021]. 
2. Brinchuk, M.M., (2010). The nature potential as a methodological basis for the development and improvement of the international environmental law. International Law, 2 (42), pp. 8-13. (In Russ.)

3. Cassese, A. and Weiler, H.H. (eds.), (1988). Change and Stability in International Law-Making. Berlin, New York: Walter de Gruyter. (In Eng.)

4. Dal, V.I., (1979). The Explanatory Dictionary of the Living Great Russian Language. Vol. 2. Moscow: Russkiy yazyk. (In Russ.)

5. Danilov-Danilyan, V.I., (1992). An interview with the Minister of Ecology and Natural Resources of the Russian Federation. Moscow Journal of International Law, 4, pp. 65-80. (In Russ.)

6. Golitsyn, V.V., (2011). Some relevant aspects of the modern development of environmental law. In: Ispolinov, A.S., Batalov, A.A. (eds). International Scientific and Practical Conference "Readings from Tunkin". Collection of reports and articles. Moscow: Moscow State University. Pp. 25-32. (In Russ.)

7. Ilyinskaya, O.I., (2010). The ways to ensure implementation of international treaties. Lex Russica, 6, pp. 1415-1420. (In Russ.)

8. Kiss, A., (1997). Introduction to International Environmental Law. Geneva: UNITAR.

9. Kolbasov, O.S., (1982). International legal protection of the environment. Moscow: Mezhdunarodnye otnosheniya. (In Russ.)

10. Kopylov, M.N., (2000). The right to development and environmental security of developing countries (international legal issues). Moscow: ECON. (In Russ.)

11. Kopylov, M.N., (2007). Introduction to the International Environmental Law. Moscow: Peoples Friendship University of Russia. (In Russ.)

12. Lukashuk, I.I., (1997). Rules of international law in the international normative system. Moscow: Spark. (In Russ.)

13. Lukashuk, I.I., (2005). International Law. Special Part. 3rd ed., rev. and suppl. Moscow: Wolters Kluwer. (In Russ.)

14. Malanczuk, P., (1997). Akehurst's modern introduction to International Law. London and New York: Routledge. (In Eng.)

15. Matuzov, N.I. and Malko, A.V., (2001). The Theory of State and Law. Moscow: Yurist. (In Russ.)

16. Medvedeva, M.O., (2010). International Environmental Law: Questions of Faith. In: Alexander Zadorozhny - 50: Articles and essays of students and colleagues. Odessa: Feniks. Pp. 219-247. (In Ukrainian) 
17. Medvedeva, M.O., (2012). Theoretical and practical aspects of the implementation of international legal norms in the field of environmental protection. Kyiv: Taras Shevchenko National University of Kyiv, Institute of International Relations. (In Ukrainian)

18. Mingazov, L.Kh., (1999). Effectiveness of the International Law. Theoretical problems. Kazan: Kazan University Publishing House. (In Russ.)

19. Repetski, V.M., Lisik, V.M., Mikievic, M. et al., (2012). International Public Law. 2nd ed. Kyiv: Znannya. (In Ukrainian)

20. Saint-Marc, Ph., (1977). Socialisation of Nature. Translated by L.M. Stepachev and Yu.A. Schkolenko. Moscow: Progress. (In Russ.)

21. Shemshuchenko, Yu.S., (2009). Plus the greening of the whole Earth (problems of codification of the International Environmental Law). Ekologicheskoe pravo, 2/3, pp. 82-85. (In Russ.)

22. Sokolova, N.A., (2003). Environmental issues in the activities of international judicial tribunals. Russian Yearbook of International Law, pp. 99-112. (In Russ.)

23. Sokolova, N.A., (2014a). Prospects for the development of International Environmental Law. In: Ispolinov, A.S., Batalov, A.A. (eds). International Scientific and Practical Conference "Readings from Tunkin". Collection of reports and articles, 4, pp. 9-18. (In Russ.)

24. Sokolova, N.A., (2014b). Traditional and modern fields of regulation of the International Security Law, Fragmentation of International Law. Liber amicorum in honor of Prof. E.G. Moiseev, pp. 378-400. (In Russ.)

25. Timoshenko, A.S., (1986). Formation and development of the International Environmental Law. Moscow: Nauka. (In Russ.)

26. Timoshenko, A.S., (1992). International environmental law, in International Law Course. In 7 volumes. Vol. 5: Branches of International Law. Moscow: Nauka. Pp. 287-336. (In Russ.)

27. Valeev, R.M., (2001). Control in the modern international law. Kazan: Innovation Technologies Center. (In Russ.)

28. Vitzthum, W. Graf et al., (2011). International Law. Translated by T. Beknazar, A. Nasyrova and N. Spitsa. Moscow: Infotropic Media. (In Russ.)

\section{Information about the author}

Olga I. Ilinskaya, Cand. Sci. (Law), Associate Professor, Department of International Law, Kutafin Moscow State Law University (MSAL)

Sadovaya-Kudrinskaya St., 9, Moscow 125993, Russia

oilinskaya@mail.ru 